\title{
Ammonia treatment of wheat straw. 2. Efficiency of microbial protein synthesis, rumen microbial protein pool size and turnover, and small intestinal protein digestion in sheep
}

\section{S.J. OOSTING ${ }^{1}$, T.C. VIETS ${ }^{2}$, S.C.W. LAMMERS-WIENHOVEN ${ }^{2}$ \& J, VAN BRUCHEM ${ }^{2}$}

I Department of Tropical Animal Production, Wageningen Agricultural University, P.O. Box 338, NL $6700 \mathrm{AH}$ Wageningen, Netherlands

2 Department of Human and Animal Physiology, Wageningen Agricultural University, Wageningen, Netherlands

Received 3 August 1992; accepted 23 February 1993

\section{Abstract}

Ammonia treated wheat straw (AWS) was compared with untreated wheat straw (UWS) and untreated wheat straw supplemented with urea (SWS) in an experiment with 6 wether sheep. Microbial protein synthesis increased due to ammonia treatment as an effect of the higher intake of rumen degradable organic matter. The efficiency of microbial protein synthesis was low for all rations, on average $22.1 \mathrm{~g} \mathrm{~N} / \mathrm{kg}$ apparently rumen degradable organic matter and was not significantly affected by ammonia treatment. Estimates of microbial protein synthesis based on diaminopimelic acid (DAPA) or the amino acid profile method did not differ significantly. The microbial DM (average $151 \mathrm{~g}$ ) and $\mathrm{N}$ pool (average $12 \mathrm{~g}$ ) in the rumen and the proportion of rumen microbes associated with the fluid phase (average $36 \%$ ) were not affected by ration, but the clearance rate of microbes tended $(p<0.10)$ to be higher for AWS $(2.9 \% / \mathrm{h})$ than for UWS $(2.1 \% / \mathrm{h})$ and SWS $(2.2 \% / \mathrm{h})$. True rumen degradation of dietary amino acid-nitrogen (AA-N) was not affected by ration (average $412 \mathrm{~g} / \mathrm{kg}$ ). Small intestinal apparent digestibilities of N, AA-N, amino acids and non-protein nitrogen (NPN) were not significantly different between rations and were on average $485,583,593$ and $313 \mathrm{~g} / \mathrm{kg}$, respectively. Apparent small intestinal AA-N absorption was significantly higher for AWS $(6,0 \mathrm{~g} / \mathrm{d})$ than for UWS $(3.8 \mathrm{~g} / \mathrm{d})$ and SWS $(4.2 \mathrm{~g} / \mathrm{d})$.

Keywords: rumen microbial pool, intestinal protein

\section{Introduction}

In ruminants, the supply of amino acids for maintenance and production depends on the availability of microbial protein and undegraded dietary protein for digestion in the small intestine. The quantity of crude protein ingested as such is only of minor importance in that respect. Microbial protein synthesis is closely related to the quantity of fermentable organic matter ingested and the amount and nature of the $\mathrm{N}$ sour- 
ce available. In low-quality fibrous feeds, crude protein content is low. About half is degraded in the reticulo-rumen and the small intestinal digestibility of the part escaping from reticulo-rumen degradation is presumed to be limited (Hvelplund, 1989), even after ammonia treatment. Hence, with such low quality fibrous diets, microbial protein synthesized in the reticulo-rumen constitutes almost the only source for protein digestion in the small intestine.

The efficiency (microbial $\mathrm{N}$ yield $/ \mathrm{kg}$ apparently rumen degraded $\mathrm{OM}$ ) of microbial protein synthesis in the rumen is related to nutrient availability and retention time of microbes in the rumen (Hespell \& Bryant, 1979). Inadequacy of nutrients as sulphur, phosphorus, true protein and branch chained volatile fatty acids can limit microbial growth without affecting energy fermentation. In addition, a longer retention time of microbes in the rumen results in a higher turnover of microbial matter due to increased lysis and predation by protozoa.

Of the protein entering the duodenum, an average true digestibility has been reported of about $85 \%$ (Van Bruchem et al., 1989). The actual supply of amino acids, however, is more closely related to the amino acid's apparent digestibility. The difference between these two digestibility measures is caused by the quantity of endogenous protein lost from the small intestine, which in turn is related to the extent at which endogenous protein is produced in the small intestine as enzymic protein, mucoprotein and shredded epithelial cells. Apparently, a considerable part of this endogenous protein is re-utilized in the small intestine (Van Bruchem et al., 1987), thus salvaging part of the constituent amino acids.

It was previously suggested that the net endogenous protein production is positively related to the quantity of cell wall constituents passing the small intestine (Van Bruchem et al., 1989). This could be of particular relevance with the highly fibrous diets fed in the present experiment. An increased endogenous protein production on top of a relatively low quantity of protein reaching the duodenum could result in an extremely low apparent protein digestibility in the small intestine. In such a situation the quantity of amino acids coming available for intermediary metabolism would particularly become a constraint, even for moderate levels of production, such as for example early growth (Ørskov, 1982).

The present paper describes the efficiency of microbial protein synthesis and the apparent small intestinal digestion of amino acids in sheep fed wheat straw as the basal diet, either supplemented with urea or treated with ammonia.

\section{Materials and methods}

The major part of materials and methods of the present experiment was described in detail by Van Bruchem et al. (1993). A summary is given below. Materials and methods not described by Van Bruchem et al. (1993) are given in detail.

Six mature sheep (wethers) with an average live weight of $44 \mathrm{~kg}$ were fitted with a rumen cannula, a silastic infusion tube in the abomasum and with T-shaped hard pvc cannulas in the proximal duodenum and terminal ileum. The experiment started 2.5 months after surgery, after the animals had well recovered.

During the experiment the animals were kept in metabolic cages and received 
equal portions of their ration every four hours. Water and a mineral lick containing $\mathrm{NaCl}, \mathrm{Fe}, \mathrm{Mg}$ and $\mathrm{Co}$ were freely available.

The animals were randomly allotted into three groups of two sheep each. Group one was fed ad libitum untreated wheat straw supplemented with pelleted sugar beet pulp (UWS). Group two was fed the same ration with an infusate into the rumen of an urea solution $(60 \mathrm{ml} / \mathrm{h}$; concentration of $5.4 \mathrm{~g}$ urea-N/l; $7.9 \mathrm{~g} \mathrm{~N}$ daily) (SWS) and group three was fed ad libitum ammoniated wheat straw also with a supplement of pelleted sugar beet pulp (AWS):

The untreated and ammoniated wheat straws were offered in a quantity of $1.8 \mathrm{~kg}$ daily allowing selection. The sugar beet pulp was supplied at a level of $240 \mathrm{~g}$ product daily. The composition of the feeds with regard to $\mathrm{N}$ and amino acid nitrogen (AA-N) is given in Table 1.

Before the start of the experiment the animals were fed untreated wheat straw during 5 weeks. The experiment consisted of a two week adaptation period and a seven week experimental period. The results presented here were derived from measurements during weeks 3,4 and 7 of the experimental period.

In the 3rd and 4th week of the experiment the flow of nutrients in the duodenum and ileum was assessed based on a continuous infusion of about $20 \mathrm{mg} \mathrm{Co}$ and 20 $\mathrm{mg} C r$ per hour into the abomasum, starting one day prior to sampling. The composition of the infusate and the sampling procedure were as described by Van Bruchem et al. (1993). Hourly samples of approximately $10 \mathrm{~g}$ of duodenal and ileal digesta were collected during four days. After collection, the samples were freeze dried, ground and pooled per animal, week and cannula. In addition to the constituents already described by Van Bruchem et al. (1993), samples were analyzed for N and amino acids including diaminopimelic acid (DAPA). Duodenal and ileal flows were estimated based on the concentration of a constituent relative to the concentration of markers. $\mathrm{N}$ was determined by the Kjeldahl method with $\mathrm{K}_{2} \mathrm{SO}_{4}$ and $\mathrm{CuSO}_{4}$ as catalysts. Amino acids, including DAPA were determined as described by Van Bruchem et al, (1988) with a Biotronic LC5001 automatic amino acid analyzer. Samples were hydrolysed under reflux with $\mathrm{HCl}(6 \mathrm{~mol} / \mathrm{l})$ at $110^{\circ} \mathrm{C}$ for $22 \mathrm{~h}$. The sulphur containing amino acids methionine and cystine were determined as methionine sulphone and cysteic acid, respectively, after performic acid oxidation (Moore, 1963).

During the morning of each sampling day, a composite sample of rumen fluid was collected from the ventral rumen sac. From these samples, rumen microbes were iso-

Table $1 . \mathrm{N}$ and $\mathrm{AA}-\mathrm{N}$ concentration $(\mathrm{g} / \mathrm{kg})$ in untreated wheat straw, ammoniated wheat straw and sugar beel pulp.

\begin{tabular}{lccc}
\hline & Untreated wheat & $\begin{array}{l}\text { Ammoniated wheat } \\
\text { straw }\end{array}$ & Sugar beet pulp \\
& straw & & \\
DM & 887 & 843 & 886 \\
$\mathrm{~N}($ in DM) & 6 & 18 & 13 \\
$\mathrm{AA}-\mathrm{N}($ in DM) & 4 & 4 & 11 \\
$\mathrm{AA}-\mathrm{N} / \mathrm{N}(\mathrm{g} / \mathrm{kg})$ & 619 & 207 & 829 \\
\hline
\end{tabular}




\section{S. J. OOSTING ET AL.}

lated by differential centrifugation $(550-70,000 \mathrm{~g})$ with an MSE superspeed 65 centrifuge at $4^{\circ} \mathrm{C}$. The pellet was washed twice with a buffer, prepared according to Meyer et al. (1967). After freeze-drying, the individual amino acids including DAPA and $\mathrm{N}$ were determined, the latter with the micro-Kjeldahl method.

Overall digestibility of $\mathrm{N}$ was measured by daily collection and subsampling of residual feed and total collection of faeces over six days in weeks 3 and 4. Faecal N excretion was not corrected for duodenal and ileal sampling, which was done during four of the six days of faecal collection. The $\mathrm{N}$ withdrawal from the duodenal and ileum was approximately $250 \mathrm{mg} / \mathrm{d}$, which, averaged over the faecal collection period means an underestimation of faecal $\mathrm{N}$ excretion of maximally $170 \mathrm{mg} / \mathrm{d}$.

During the 7th week of the experiment total rumen evacuations were conducted in such a schedule, that of all animals total rumen contents were measured and a proportional sample for analyses of DM and DAPA was taken at 1,2 and 3 hours after feeding. Analyses were done in samples pooled per animal. A sample of the fluid phase was taken by straining whole rumen contents over cheese cloth. After pooling per animal, these samples were analyzed for DM and DAPA. The DAPA pool associated with rumen fluid was calculated as concentration of DAPA in rumen fluid times rumen fluid pool (rumen contents minus rumen DM pool). The DAPA pool in the particulate phase was estimated by subtracting the fluid phase DAPA pool from the total rumen DAPA pool. Microbial $\mathrm{N}$ and DM pools were estimated by multiplication of the DAPA pool with the N/DAPA- or DM/DAPA-ratio as found in isolated rumen microbes.

Statistical analysis was done on means per animal (average of two repeated measurements) by the program DBSTAT (Brouwer, 1989). The model to test the ration effect on observed or estimated parameters $(\mathrm{Y})$ was: $\mathrm{Y}_{\mathrm{ij}}=$ mean + ration $_{\mathrm{i}}+$ error $_{\mathrm{ij}}$, with total degrees of freedom (d.f.) 6 . To test the significance of contrasts: L1: -1 . UWS -1 . SWS +2 . AWS and L2: -1 . UWS +1 . SWS the ration sum of square was subdivided in the sum of square of each contrast with d.f. $=1$. The d.f. of the crror term was 3. (Snedecor \& Cochran, 1967). The level of significance of a contrast was indicated in tables for $\mathrm{p}<0.25(\S), \mathrm{p}<0.10(\dagger), \mathrm{p}<0.05\left({ }^{*}\right), \mathrm{p}<0.01\left({ }^{* *}\right)$ and $\mathrm{p}<0.001(* * *)$.

\section{Results}

\section{Rumen microbes}

Table 2 presents the composition of rumen microbes. The microbes in the rumen of sheep fed AWS tended $(\mathrm{p}<0.10)$ to contain less N, AA-N and total amino acids in the DM, while the DAPA concentration in microbial DM of sheep fed AWS was significantly lower than of sheep fed UWS or SWS. The ratio AA-N/total N tended ( $p<$ $0.10)$ to be lower in microbes of sheep fed AWS than of microbes of sheep fed UWS or SWS. The ratio DAPA-N/total microbial N was $6.1,6.8$ and $5.5 \mathrm{~g} / \mathrm{kg}$ (SEM 0.32) for UWS, SWS and AWS, respectively. Ammonia treatment tended $(\mathrm{p}<0.10)$ to decrease the DAPA-N/total N ratio in rumen microbes.

In Table 3, the microbial DM and $\mathrm{N}$ pool in the rumen is given as well as the dis- 
Table 2. Composition of rumen microbes.

\begin{tabular}{|c|c|c|c|c|c|c|}
\hline \multirow{2}{*}{$\begin{array}{r}1 \\
1 \quad \\
1\end{array}$} & \multirow[t]{2}{*}{ Uws' } & \multirow[t]{2}{*}{ sws } & \multirow[t]{2}{*}{ AWs } & \multicolumn{2}{|c|}{$\begin{array}{l}\text { Significance } \\
\text { of contrast }\end{array}$} & \multirow[t]{2}{*}{ SEM } \\
\hline & & & & L1 & L2 & \\
\hline DAPA (mmol/kg DM) & 18 & 20.5 & 14.9 & * & $\S$ & 0.94 \\
\hline Amino Acids (mol/kg DM) & 3.5 & 3.6 & 3.1 & $t$ & ns & 0.14 \\
\hline $\mathrm{N}(\mathrm{g} / \mathrm{kg} \mathrm{DM})$ & 83 & 84 & 76 & $t$ & ns & 2.4 \\
\hline $\mathrm{AA}-\mathrm{N}(\mathrm{g} / \mathrm{kg} \mathrm{DM})$ & 60 & 62 & 54 & $t$ & ns & 2.3 \\
\hline $\mathrm{AA}-\mathrm{N} / \mathrm{N}(\mathrm{g} / \mathrm{kg})$ & 729 & 737 & 715 & $t$ & ns & 5.4 \\
\hline
\end{tabular}

n': not significant; $\$$ : $<<0.25 ; \uparrow: \mathrm{p}<0.10 ;{ }^{*}: \mathrm{p}<0.05$. L1: contrast $-1 \cdot$ UWS $-1 \cdot$ SWS $+2 \cdot$ AWS. L2: contrast -1 - UWS +1 - SWS.

tribution of microbial matter between fluid and particulate phases. The rate of clearance of microbial matter from the rumen $\left(\mathrm{k}_{\mathrm{cl}, \text { microbes }}\right)$ was calculated as the hourly DAPA flow in the duodenum as percentage of the rumen DAPA pool.

No significant differences between rations were observed for microbial DM or $\mathrm{N}$ pool. The microbial DM pool contributed for 179,151 and $174 \mathrm{~g} / \mathrm{kg}$ to the total rumen DM pool for UWS, SWS and AWS, respectively $(p>0.10)$. The proportion of total microbial DAPA, that was associated with the fluid phase was not different between rations and averaged $36.0 \%$. The concentration of microbial $\mathrm{N}$ in rumen fluid was not significantly different between rations. The rate of clearance of rumen microbes from the rumen microbial pool tended $(p<0.10)$ to be higher for AWS than for UWS and SWS.

The quantity of microbial protein synthesized in the rumen was determined by different methods:

Table 3. Sizc, proportion associated with liquid phase and rate of clearance of rumen pool of microbes.

\begin{tabular}{|c|c|c|c|c|c|c|}
\hline \multirow[b]{2}{*}{$\therefore$} & \multirow[t]{3}{*}{ UWS } & \multirow[t]{3}{*}{ sws } & \multirow[t]{3}{*}{ AWS } & \multicolumn{2}{|c|}{$\begin{array}{l}\text { Significance } \\
\text { of contrast }\end{array}$} & \multirow[t]{3}{*}{ SEM } \\
\hline & & & & LI & L2 & \\
\hline 1 & & & & & & \\
\hline Microbial DM pool (g) & 136 & 137 & 179 & $\S$ & ns & 18.1 \\
\hline Microbial N pool (g) & 11.2 & 11.5 & 13.6 & $\S$ & ns & 1.27 \\
\hline $\begin{array}{l}\text { Microbial pool associated } \\
\text { with fluid (\% of rumen } \\
\text { microbial pool) }\end{array}$ & 35.9 & 35.2 & 37.0 & ns & ns & 1.60 \\
\hline $\begin{array}{l}\text { Concentration of microbial } \\
N \text { in rumen fluid }(\mathrm{mg} / \mathrm{l})\end{array}$ & 735 & 636 & 597 & ns & ns & 84.9 \\
\hline$k_{c l, \text { mlcrobes }}(\% / h)$ & 2.1 & 2.2 & 2.9 & $t$ & ns & 0.22 \\
\hline
\end{tabular}

ns; not significant; $\S: \mathrm{p}<0.25 ; \ddagger$ p $<0.10$. L1: contrast $-1 \cdot$ UWS $-1 \cdot$ SWS $+2 \cdot$ AWS. L2: contrast $-1 \cdot$ UWS + 1. SWS. 


\section{S, J, OOSTING ET AL.}

1) DAPA: The DAPA flow (mole/day) in the duodenum was multiplied with the N/DAPA-ratio ( $\mathrm{g} / \mathrm{mole})$ as found in isolated rumen microbes.

2) Amino Acid Profile method (AAP): Dietary, microbial and endogenous proteins (Table 4) were mixed by an iterative procedure in such proportions, that the computed AAP matched best to the actual AAP of duodenal protein. This was tested by minimizing the objective function:

$\sum_{A A=1}^{A A=16}\left(1-\mathrm{AA}_{\text {computed }} / \mathrm{AA}_{\text {actual }}\right)^{2}$

This procedure was done for 16 amino acids (AA), leaving out cystine, due to the high analytical variation. The AAP is given in molar percentages and the AAP of endogenous protein (bovine pepsinogen) was adapted from Siddons et al. (1982). Since only marginal and insignificant differences were observed for the AAP of diets and rumen microbes between animals and rations the calculation of proportions of feed, microbial and endogenous AA-N in duodenal digesta was done on the average of all dicts and rumen microbes. The obtained partition of duodenal AA-N in endogenous, microbial and feed AA-N is given in Table 4.

Table 4. Amino acid profiles (molar \%) of endogenous, dietary, rumen microbial and duodenal (DUWS, D-SWS and D-AWS) proteins and proportion of amino acids of microbial, feed and endogenous origin in duodenal digesta.

\begin{tabular}{|c|c|c|c|c|c|c|c|}
\hline , & & Endogenous ${ }^{l}$ & Diet $^{2}$ & Microbes $^{2}$ & D-UWS & D-SWS & D-AWS \\
\hline Cystine & & n.a. & 1.26 & 0.70 & 1.22 & 1.10 & 1.12 \\
\hline Aspartic acid & & 11.50 & 9.48 & 11.37 & 10.58 & 10.65 & 11.11 \\
\hline Methionine & & 1.08 & 2.00 & 2.12 & 1.63 & 1.70 & 1.70 \\
\hline Threonine & & 7.63 & 5.90 & 6.40 & 6.36 & 6.41 & 6.41 \\
\hline Serine & & 14.32 & 7.35 & 5.90 & 6.68 & 6.55 & 6.55 \\
\hline Glutamic acid & & 9.22 & 10.77 & 10.49 & 10.27 & 10.39 & 10.20 \\
\hline Proline & & 4.43 & 4.84 & 3.67 & 4.66 & 4.24 & 3.78 \\
\hline Glycine & , & 9.94 & 9.52 & 9.23 & 9.35 & 9.40 & 9.44 \\
\hline Alanine & & 4.60 & 9.01 & 10.34 & 9.87 & 10.10 & 9.75 \\
\hline Valine & & 7.12 & 7.01 & 6.93 & 6.62 & 6.97 & 6.77 \\
\hline Isoleucine & ; & 9.01 & 4.19 & 5.75 & 5.28 & 5.35 & 5.39 \\
\hline Leucine & & 7.20 & 6.63 & 7.07 & 7.33 & 7.33 & 7.18 \\
\hline Tyrosine & * & 5.08 & 3.40 & 3.60 & 3.35 & 3.27 & 3.31 \\
\hline Phenylalanine & , & 4.29 & 3.36 & 3.80 & 3.72 & 3.75 & 3.68 \\
\hline Lysine & & 2,30 & 4.85 & 6.55 & 6.21 & 5.49 & 6.34 \\
\hline Histidine & & 0.56 & 6.15 & 2.66 & 3.48 & 3.78 & 3.95 \\
\hline Arginine & & 1.72 & 4.28 & 3.42 & 3.38 & 3.50 & 3.34 \\
\hline \multicolumn{8}{|c|}{ Proportion of duodenal AA (\%) } \\
\hline \multicolumn{5}{|c|}{ Microbial AA } & 62 & 57 & 64 \\
\hline \multirow{2}{*}{\multicolumn{5}{|c|}{ Feed AA }} & 30 & 36 & 31 \\
\hline & & \multicolumn{3}{|c|}{ Endogenous AA } & 8 & 7 & 5 \\
\hline
\end{tabular}

1 Composition of bovine pepsinogen adapted from Siddons et al. (1982). ${ }^{2}$ Mean for the 3 rations. n.a. not available. 
The efficiency of microbial protein synthesis is presented in Table 5. No significant differences were observed between rations. No differences between methods of estimation (DAPA or AAP) of the efficiency of microbial protein synthesis were found. For the results based on DAPA the $\mathrm{Y}_{\text {ATP }}(\mathrm{g}$ cell DM/mol ATP) was calculated from the efficiency of microbial protein synthesis per kg TRDOM (truly rumen degradable organic matter) ingested (Van Soest, 1982). Per kg TRDOM 28.4 moles of ATP are produced, assuming a molecular weight of glucose in carbohydrates of 162 and an ATP formation of $4.6 \mathrm{moles} / \mathrm{mol}$ glucose (Czerkawski, 1986). Calculation of the latter value was based on the volatile fatty acid pattern found in rumen fluid (Van Bruchem et al:, 1993).

The maintenance coefficient of the microbial population $\left(\mathrm{M}_{e}\right.$, mol ATP/g cell $\mathrm{DM} / \mathrm{h}$ ) was estimated from the model:

$$
1 / Y_{A T P}=1 / Y_{N T P}^{M A X}+M_{c} / k_{c l, m i c r o b e s}
$$

with: $Y_{A T P}^{M A X}=$ maximal cell DM yield $(\mathrm{g})$ per mol ATP; $k_{\text {cl,microbes }}=$ rate of clearance of microbes from the rumen, expressed as fraction/h. (adapted from De Vries et al, 1970).

The above given equation implies, that in vivo, given a constant $Y_{\text {ATP }}^{\mathrm{MAX}}$, the net $Y_{A T P}$ is determined by $k_{c l, m i c r o b e s}$ and $M_{e}$. The $k_{c l, m i c r o b e s}$ determines the retention time of microbes in the rumen and consequently the probability of predation by protozoa, which is the major determinant of microbial turnover in the rumen (Demeyer \& Van Nevel, 1979). To get an estimate for $\mathrm{Y}_{\text {ATP }}^{\mathrm{MAX}}$ the model was fitted to in vitro data derived from continuous cultures of mixed rumen microbes at various rates of clearances with glucose as the sole energy substrate as reported by Isaacson et al. (1975) and Van Nevel \& Demeyer (1979). The regression line obtained was: $1 / Y_{\text {ATP }}$

Table 5, Efficiency of microbial protein synthesis and rumen degradability of feed AA-N.

\begin{tabular}{|c|c|c|c|c|c|c|}
\hline \multirow{2}{*}{$\begin{array}{r}1 \\
\quad \\
.\end{array}$} & \multirow{2}{*}{ UWS } & \multirow{2}{*}{ sws } & \multirow[t]{2}{*}{ AWS } & \multicolumn{2}{|c|}{$\begin{array}{l}\text { Significance } \\
\text { of contrast }\end{array}$} & \multirow[t]{2}{*}{ SEM } \\
\hline & & & & Ll & L2 & \\
\hline \multicolumn{7}{|c|}{ Eflelency microbial protein synthesis ( $\mathrm{g} N / \mathrm{kg}$ ARDOMI') } \\
\hline DAPA & $24.1^{10}$ & 22.8 & 19.4 & $\S$ & ns & 2.15 \\
\hline AAP & 25.0 & 22.0 & 18.5 & $\S$ & ns & 2.45 \\
\hline$Y_{\text {ATP }}^{\prime}(\mathrm{g} \text { cell DM/mol ATP })^{2}$ & 8.0 & 7.7 & 7.4 & ns & ns & 0.45 \\
\hline $\mathrm{M}_{s}^{3}(\mathrm{mmol}$ ATP/g cell DM/h) & 1.6 & 1.7 & 2.5 & $*$ & ns & 0.13 \\
\hline \multicolumn{7}{|c|}{ Rumen degradability of feed $A A-N(\mathrm{~g} / \mathrm{kg})$} \\
\hline DAPA & $422^{\circ}$ & 444 & 463 & ns & ns & 59.9 \\
\hline $\mathrm{AAP}$ & 463 & 368 & 406 & ns & $\S$ & 36.2 \\
\hline
\end{tabular}

ns: not significant; $\S: \mathrm{p}<0.25 ; *$ p $<0.05$. L1: contrast $-1 \cdot$ UWS $-1 \cdot$ SWS $+2 \cdot$ AWS. L2: contrast -1 . UWS + 1 - SWS, 'ARDOMI: Apparently rumen degraded organic matter intake. ${ }^{2}$ Based on DAPA, ${ }^{3}$ Based on DAPA, $M_{c}=$ Maintenance coefficient of microbial population. 
$=0.0508+0.00126 / \mathrm{k}_{\text {cl,microbes }}\left(\mathrm{n}=7, \mathrm{R}^{2}=0.88, \mathrm{RSD}=0.007\right)$, indicating an $\mathrm{Y}_{\mathrm{ATP}}^{\mathrm{MAX}}$ of $19.7 \mathrm{~g}$ cell DM/mol ATP, close to the theoretically derived estimate of $22-24 \mathrm{~g}$ cell DM/mol ATP given by Hespell \& Bryant (1979) and a maintenance coefficient of $1,26 \mathrm{mmol}$ ATP/g cell DM/h.

Based on the $\mathrm{Y}_{\mathrm{NTP}}^{\mathrm{MAX}}$ estimated for rumen microbes in continuous cultures and the $k_{\mathrm{cl}, \text { microbes }}$, the $\mathrm{M}_{\mathrm{c}}$ of the microbial populations was calculated for the various rations. The $M_{c}$ was significantly higher AWS than for UWS and SWS.

No difference between rations was observed with regard to the rumen degradation of feed AA-N. The AA-N degradation was computed assuming an endogenous AA-N flow in the duodenum as derived from the AAP method. The microbial AA-N flow was calculated from the AAP method or the DAPA method and the duodenal feed $\mathrm{AA}-\mathrm{N}$ flow was equal to total AA-N flow minus endogenous and microbial AA-N flow.

\section{Nitrogen supply}

Intake, duodenal and ileal flows and faecal excretion of $\mathrm{OM}, \mathrm{N}$ and $\mathrm{AA}-\mathrm{N}$ are presented in Table 6. Intake of OM, N and AA-N of AWS was significantly higher than of UWS and SWS. The N intake from SWS was $8.4 \mathrm{~g} /$ day higher than from UWS of which $7.9 \mathrm{~g} /$ day was due to infusion of urea into the rumen. Duodenal flow of OM tended $(p<0.10)$ to be higher for AWS than for UWS and SWS and duodenal flows of $\mathrm{N}$ and AA-N were significantly higher for AWS than for UWS and SWS. The duodenal flows of N and AA-N in case of UWS and of AA-N in case of SWS and AWS were higher than the intake of these nutrients, indicating the importance of influx of $\mathrm{N}$ into the rumen through saliva and diffusion through the rumen wall in case of UWS and the incorporation of ammonia into amino acids by rumen microbes for all rations.

The microbial, feed and endogenous AA-N flows in the duodenum as estimated by the AAP method are also given in Table 6. The microbial AA-N flows estimated by DAPA were: $4.0,4.4$ and $6.8 \mathrm{~g}$ /day for UWS, SWS and AWS respectively (SEM $0.31)$. The microbial AA-N $(\mathrm{p}<0.05)$ and the undegraded feed AA-N $(\mathrm{p}<0.10)$ flows in the duodenum were higher for AWS than for UWS and SWS. No significant differences in endogenous AA-N flows were found between rations. The ratio AA-N/N in the duodenum was significantly lower in AWS than in UWS and SWS.

The ileal flow of $\mathrm{N}$ was significantly higher for AWS than for UWS and SWS, while the ileal flow of AA-N tended $(p<0.10)$ to be higher for AWS than for UWS and SWS. The AA-N/N ratio in the ileum differed significantly between rations and was highest for UWS and lowest for AWS.

The apparent absorption of AA-N in the small intestine was 3.8, 4.2 and $6.0 \mathrm{~g} /$ day (SEM 0.30) for UWS, SWS and AWS, respectively. The apparent daily absorption was significantly higher for AWS than for UWS and SWS.

The faecal excretion of $\mathrm{N}$ in case of AWS was significantly higher than in case of UWS and SWS. Some disappearance of $\mathrm{N}$ occurred in the large intestine: 1.4, 1.7 and $1.9 \mathrm{~g} /$ day or 286,298 and $203 \mathrm{~g} / \mathrm{kg}$ ileal $\mathrm{N}$ flow for UWS, SWS and AWS, respectively. These values did not differ significantly between rations. The disappearan- 
Table 6, Intake and flow at duodenum and ileum and faecal excretion of $\mathrm{OM}, \mathrm{N}$ and $\mathrm{AA}-\mathrm{N}$.

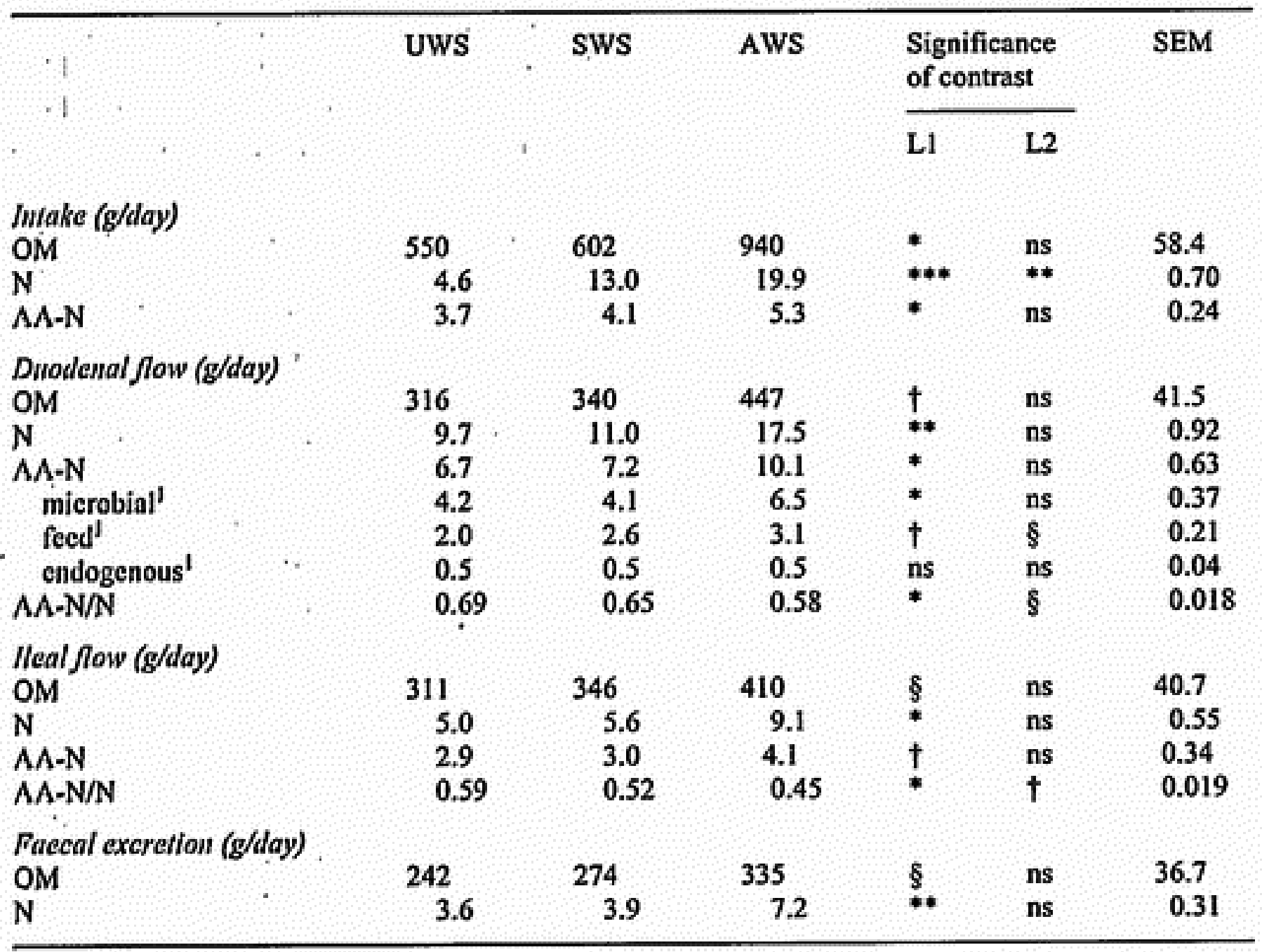

ns: not significant; $\S: \mathrm{p}<0.25 ; \uparrow: \mathrm{p}<0.10 ; *$ : $<<0.05 ;{ }^{* *}$ : $\mathrm{p}<0.01 ;{ }^{* * *}$ : $\mathrm{p}<0.001$. L1: contrast -1 . UWS $-1 \cdot$ SWS $+2 \cdot$ AWS. L2: contrast $-1 \cdot$ UWS $+1 \cdot$ SWS. ${ }^{1}$ Based on AAP.

ce of $\mathrm{N}$ in the hindgut was for all rations more than the maximal underestimation (due to withdrawal of $\mathrm{N}$ through duodenal and ileal sampling) of faecal $\mathrm{N}$ excretion of maximally $170 \mathrm{mg} /$ day.

Whole tract apparent $\mathrm{N}$ digestion was 228,697 and $635 \mathrm{~g} / \mathrm{kg} \mathrm{N}$ ingested for UWS, SWS and AWS, respectively. UWS had a significant lower apparent whole tract $\mathrm{N}$ digestibility than SWS and AWS, while SWS and AWS did not differ significantly. True whole tract $\mathrm{N}$ digestibility was estimated from the following Lucas equation (Van Soest, 1982):

$\mathrm{DN}=\mathrm{a} \cdot \mathrm{N}-\mathrm{b}$

with: $\mathrm{DN}=$ intake of digestible $\mathrm{N}(\%$ of $\mathrm{OMI}) ; \mathrm{N}=$ intake of $\mathrm{N}(\%$ of $\mathrm{OMI}) ; \mathrm{b}=$ metabolic faecal N (\% of OMI); a = true digestibility of N (fraction).

The model was fitted to all data including the repeated measurements. The variation in $\mathrm{N}$ concentration in OMI was mainly caused by $\mathrm{N}$ added through ammonia treatment or urea supplementation. Hence, fitting of the model for UWS and SWS gave an estimate for the true digestibility of $\mathrm{N}$ added through the urea infusate and 
fitting of the model for UWS and AWS gave an estimate for the true digestibility of $\mathrm{N}$ added through ammonia treatment. The obtained Lucas equations were (between brackets s.e. of estimate): $\mathrm{DN}=-0.65(0.029)+1.00(0.017) \cdot \mathrm{N}$ for $\mathrm{N}$ added through the urea infusate and $\mathrm{DN}=-0.56(0.045)+0.89(0.028) \cdot \mathrm{N}$ for $\mathrm{N}$ added through ammonia treatment. The true digestibility of $\mathrm{N}$ added through ammonia treatment was significantly lower than 1.

The apparent small intestinal digestibility of N, AA-N, NPN, individual and total amino acids is given in Table 7. No differences were observed between rations, only phenylalanine had a significantly lower apparent small intestinal digestibility for UWS than for SWS and AWS. The apparent small intestinal digestibility of AA-N was higher than of NPN.

Van Bruchem et al. (1989) related ileal endogenous protein losses to the duodenal non protein dry matter (NPDM) flow. The duodenal NPDM flows in the present experiment were 371,393 and $518 \mathrm{~g} / \mathrm{d}$ for UWS, SWS and AWS, respectively (SEM $30.1)$. Assuming a true small intestinal digestibility of AA-N of 0.85 as observed by Van Bruchem et al. (1989), Hvelplund \& Hesselholt (1987) and Storm et al. (1983)

Table 7. Apparent digestibility $(\mathrm{g} / \mathrm{kg})$ of AA-N, N, NPN and individual amino acids in the small intestine.

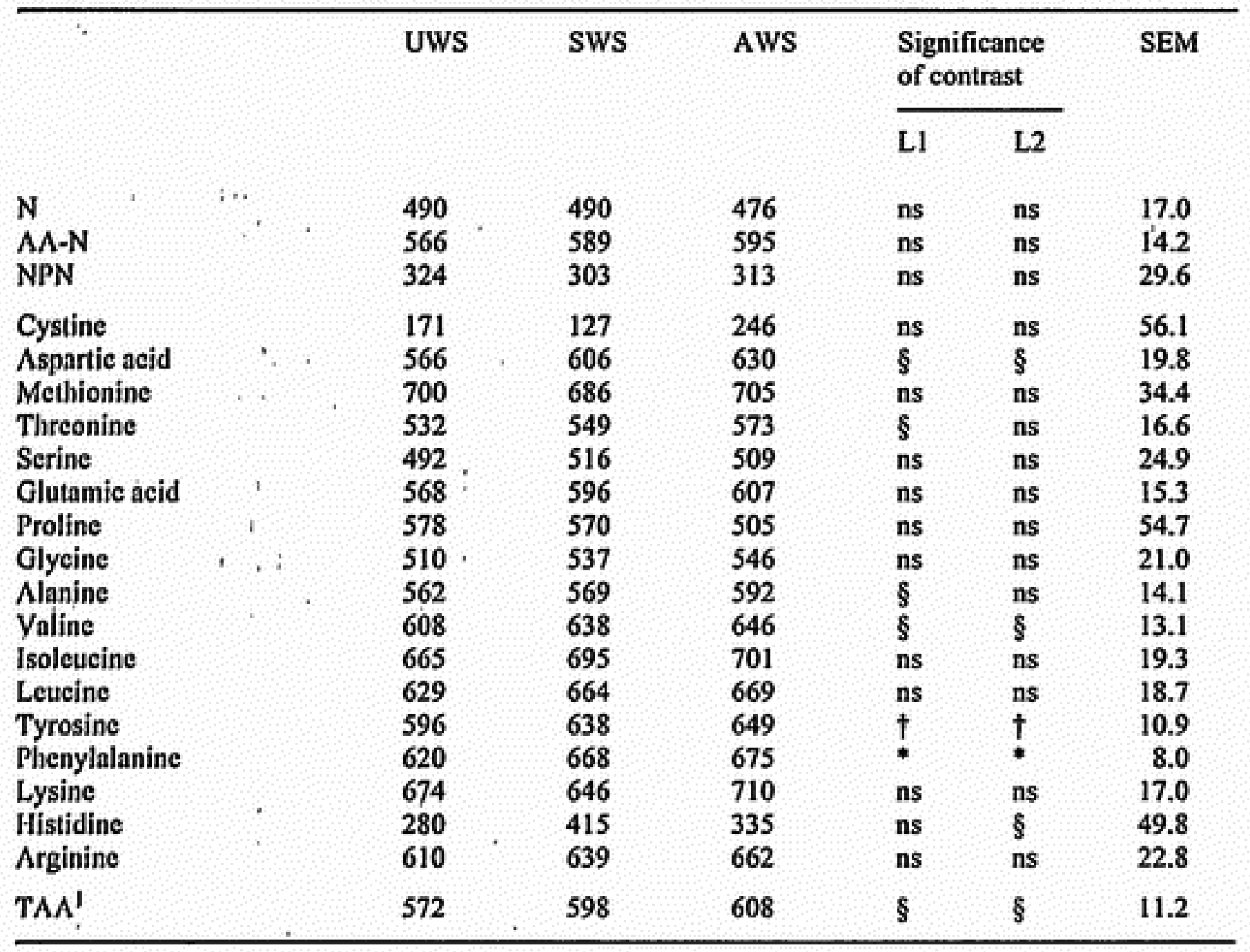

ns' not significant; $\S: \mathrm{p}<0.25 ; \mathrm{t}: \mathrm{p}<0.10 ; *$; $<0.05$. L1: contrast $-1 \cdot$ UWS $-1 \cdot$ sWS $+2 \cdot$ AWS. L2; contrast $-1 \cdot$ UWS +1 : SWS. ' Total amino acids. 
the endogenous AA-N flows (ileal flows $-0.15 \cdot$ duodenal flows) at the ileum were $5.1,4.9$ and $5.0 \mathrm{mg} / \mathrm{g}$. NPDM for UWS, SWS and AWS, respectively (SEM 0.08).

\section{Discussion}

\section{Rumen microbes}

Rumen microbes isolated from the rumen of sheep fed AWS contained significantly less DAPA and tended $(p<0.10)$ to contain less amino acids, N and AA-N in DM. The ratio DAPA-N/total microbial $\mathrm{N}$ was also lower $(\mathrm{p}<0.10)$ for AWS than for UWS and SWS. The DAPA-N/total microbial N ratios as observed in the present experiment were in line with results published by Dufva et al. (1982), Siddons et al. (1982) and Van Bruchem et al. (1985). The composition of rumen microbes is influenced by the ration as illustrated by Dufva et al. (1982), who observed that the $\mathrm{N}$ concentration in microbial DM and the DAPA-N/total microbial $\mathrm{N}$ was higher for rumen microbes isolated from the rumen of cattle fed a high roughage ration than for rumen microbes isolated from the rumen of cattle fed a high concentrate ration. Variation in DAPA-N content of total microbial $\mathrm{N}$ can probably be attributed to variation in relativeicontribution of various microbial strains to the microbial pool, since microbial strains may differ in DAPA-N/total microbial $\mathrm{N}$ ratio (Dufva et al., 1982). The lower N, AA-N and amino acid content in DM of rumen microbes with AWS as substrate could probably also be an indication of a different microbial population, but could also be attributed to a higher content of polysaccharides in individual microbial strains as this is likely to vary with ration (Czerkawski, 1986). The higher maintenance requirements for the microbial population in the rumen of sheep fed AWS compared with UWS/SWS could also be a result of the different composition of the rumen microbial pool. Microbial strains differ with regard to maintenance requirements (Hespell \& Bryant, 1979). However, individual strains of rumen microbes may show increased maintenance requirements in situations of imbalanced nutrient availability i.e. limited supply of $\mathrm{N}$, sulphur, phosphorus or true protein relative to energy availability (Nocek \& Russell, 1988). Whether the higher maintenance requirements of the rumen microbial population for AWS compared with UWS/SWS should be attributed to a different composition of the rumen microbial pool or to imbalanced nutrient supply is unknown.

Though the composition of rumen microbes differed, the amino acid profiles of rumen microbes did not differ between rations, and were neither differing much from microbial amino acid profiles found in other experiments (Siddons et al., 1982; Van Bruchem et al. (1985 and 1988), Storm \& Ørskov, 1983; Hvelplund \& Hesselholt, 1987; Tas et al., 1981).

The microbial biomass associated with rumen fluid phase was on average $36.0 \%$ of the total microbial biomass. In a review of various experiments, Owens \& Goctsch (1986) reported, that the proportion of the microbial biomass associated with the fluid phase varied from 20 to $47 \%$. The remaining fraction of the microbial biomass is associated with feed particles and the rumen wall (Cheng \& Costerton, 1980). 


\section{S, J. OOSTING ET AL.}

Ammonia treatment tended to increase the clearance rate of rumen microbes. Ammonia treatment affected neither the rate of clearance of particles from the rumen (Van Bruchem et al., 1993) nor the distribution-of the microbial pool between the fluid and particulate phase. The higher clearance rate of rumen microbes in case of AWS should therefore partly be attributed to passage rate of fluid, which was $20 \%$, though not significantly higher (Van Bruchem et al., 1993). However, differences between rations in concentration of microbes on particles passing from the rumen could also; result in different clearance rates of rumen microbes.

The concentration of microbial $\mathrm{N}$ (on average $656 \mathrm{mg} / \mathrm{l}$ ) was much higher than the concentration of $\mathrm{NH}_{3}-\mathrm{N}$ in rumen fluid, which was 43,225 and $175 \mathrm{mg} / \mathrm{l}$ for UWS, SWS and AWS, respectively (Van Bruchem et al., 1993).

\section{Efficiency of microbial protein synthesis}

Calculation of the proportion of feed, endogenous and microbial amino acids in the duodenal digesta with the amino acid profile method yielded similar results for all rations. The average proportions of microbial, endogenous and feed amino acids in the total amino acid flow in the duodenum were respectively 61,32 and $7 \%$. The amino acid profile method is based on many assumptions, which may not always be valid as discussed by Siddons et al. (1982). In addition, the endogenous fraction is likely to contain proteins from other sources than pepsinogen (Harrop, 1974) and feed protein arriving at the duodenum may have a different amino acid profile than the feed ingested.

Estimation of the microbial AA-N flow at the duodenum by DAPA or the AAP method were not differing significantly as also observed by Evans et al. (1975) and Van Bruchem et al. (1985). However, Siddons et al. (1982) and Voigt et al. (1991) observed lower estimates of microbial AA-N production for the amino acid profile method than for. DAPA, while van Bruchem et al. (1988) observed higher values for the amino acid profile method than for DAPA.

The observed efficiencies of microbial $N$ synthesis (averaged over rations 22.1 and $21.8 \mathrm{~g} \mathrm{~N} / \mathrm{kg}$ ARDOM for DAPA and AAP, respectively) were low if compared with the constant of $32 \mathrm{~g} \mathrm{~N} / \mathrm{kg}$ ARDOM as given by ARC (1980) for sheep and with values observedi in sheep by Van Bruchem et al. (1985) for diets including mixed concentrates with proteins varying in rumen degradability. However, the efficiency of microbial $\mathrm{N}$ in the present experiment did not differ from estimates based on DAPA reported by Van Bruchem et al. (1988) for alfalfa and grass silages fed to sheep and estimates given by Zorrilla-Rios et al. (1991) for untreated wheat straw fed to cattle. The latter authors observed, however, a higher efficiency for ammoniated wheat straw than for untreated wheat straw, which was not observed in the present experiment.

Urea supplementation did not increase the efficiency of microbial protein synthesis, indicating, that NPN was not the first limiting nutrient for microbial protein synthesis. Other nutrients essential for microbial protein synthesis as sulphur and phosphorus (not supplemented in the present experiment) and true protein as a source of oligo-peptides and branch chained volatile fatty acids (Hespell \& Bryant, 
19.79) could have been more limiting. From the true rumen degradation of feed AA-N it was calculated, that 59,63 and $67 \%$ (SEM 4.2) of the microbial AA-N flow in the duodenum was produced from NPN for UWS, SWS and AWS, respectively. Nolan \& Stachiw (1979) observed, that $62 \%$ of the microbial $N$ was derived from ammonia for sheep on a wheat straw based diet. These values suggest, that $30-40 \%$ of microbial protein should be synthesized from true protein. It was therefore likely, that rumen availability of true protein was limiting microbial protein synthesis in the rumen.

Efficiency of microbial protein synthesis increases with increasing flow rate of microbes due to a reduction in microbial turnover (due to predation by protozoa) and decreases with increasing maintenance requirements of the microbial population (De Vries et al., 1970; Hespell \& Bryant, 1979). The flow rate of microbes is related to the flow rate of fluid and particulate phase (Oldham, 1984). Although on average $64 \%$ of the microbial pool was associated with the particulate phase in the rumen, the contribution of fluid phase associated microbial matter to the duodenal flow of microbes may be equally or more important than the contribution of the particulate phase associated microbes. The flow rate of the fluid phase associated microbes is probably closely related to the fractional flow rate of the fluid phase, which was higher than the fractional flow rate of the particulate phase (Van Bruchem et al., 1993). In addition, of the cell walls passing from the rumen approximately $75 \%$ of the potentially degradable fraction was degraded in the rumen (Van Bruchem et al., 1993). It is therefore likely, that the concentration of microbial matter on particles leaving the rumen was lower than on particles in the rumen.

\section{Digestibility of $A A-N$ and $N$}

The true rumen digestibility of feed AA-N was on average $412 \mathrm{~g} / \mathrm{kg}$ AA-N ingested (based on AAP method) without significant differences between rations. The AA-N/N ratio in duodenal digesta was lower for AWS than for UWS and SWS, indicating, a relatively higher NPN flow for AWS than for the other rations. Duodenal NPN flows were 3.0,3.8 and 7.4 g/d (SEM 1.0) for UWS, SWS and AWS, respectively; Ammonia-N flows from the rumen were $0.4,1.9$ and $2.7 \mathrm{~g} / \mathrm{d}$ for UWS, SWS and AWS, respectively (Van Bruchem et al., 1993) and could only partly explain the difference in NPN flow between rations. Other factors, that could contribute to the higher NPN flow found with AWS compared with UWS/SWS were the lower AA-N/N ratio found in rumen microbes for AWS and the fact, that part of the N added through ammonia treatment was not available. The latter was confirmed by the fact, that the true whole tract digestibility of $\mathrm{N}$ added through ammonia treatment was significantly lower than 1 .

The apparent small intestinal digestion of amino acids and AA-N did not differ between rations. Van Bruchem et al. (1989) reported the following relation between duodenal amino acid and duodenal NPDM flow and ileal AA-N flow based on a number of experiments in which various roughages and roughage/concentrate mixtures were fed to sheep: 


\section{S. J. OOSTING ET AL.}

Ileal amino acid flow $(\mathrm{mmol} / \mathrm{h})=2.498+0.152 \cdot$ duodenal amino acid flow $(\mathrm{mmol} / \mathrm{h})+0.4134 \cdot$ duodenal NPDM flow $(\mathrm{g} / \mathrm{h})$.

This formula indicates, that the true small intestinal digestibility of amino acids is $848 \mathrm{mmol} / \mathrm{mol}$ and that the endogenous amino acid flow in the ileum is related to the NPDM flow in the duodenum. The apparent small intestinal amino acid digestibility is thus negatively related to the NPDM and positively related to the amino acid flow in the duodenum. A positive correlation between amino acid flow in the duodenum and the apparent small intestinal digestibility of amino acids was also found by Willms et al. (1991).

With a relatively low duodenal amino acid flow and a high NPDM flow a low apparent small intestinal amino acid digestibility in the small intestine is expected. Based on the equation given above the apparent small intestinal amino acid digestibilities in the present experiment would be 30,31 and $38 \%$ for UWS, SWS and AWS, respectively. The observed apparent small intestinal amino acid digestibilities were 57,60 and $61 \%$ for UWS, SWS and AWS, respectively. A lower ileal flow of endogenous amino acids could account for the difference between the estimates based on the equation of Van Bruchem et al. (1989) and the observed values in the present experiment. Recalculation of the results of Van Bruchem et al. (1989) reveals an ileal endogenous AA-N flow of $7.9 \mathrm{mg} / \mathrm{g}$ NPDM as derived from a model without intercept. Assuming a true digestibility of duodenal AA-N of $85 \%$, then ileal endogenous AA-N losses would amount on average $5.0 \mathrm{mg} / \mathrm{g} \mathrm{NPDM}$. This value would become even lower if the true digestibility of undegraded straw protein would be lower than $85 \%$ as suggested by Hvelplund (1989). It thus seems, that sheep fed on these low quality feeds adapt their amino acid requirements by lowering ileal losses of endogenous protein.

The value for the apparent small intestinal AA-N digestibility of SWS corresponds with the apparent small intestinal digestibility of non-ammonia-N (NAN) of $58 \%$ reported by Zorrilla-Rios et al. (1991) for untreated wheat straw supplemented with urea fed to cattle. These authors reported, however, a lower small intestinal degradability of NAN for ammoniated wheat straw of $48 \%$ for ammoniated wheat straw than for urea supplemented wheat straw. Willms et al. (1991) observed an apparent small i intestinal digestion of amino acids for alkaline hydrogen peroxide treated wheat straw supplemented with soybean meal fed to sheep of $45.7 \%$ for the lowest supplementation level ( $8.5 \% \mathrm{CP}$ in the ration) used in their experiment. In this situation the duodenal NPDM and amino acid flow approximated the values for AWS. Cecava et al. (1990) observed slightly higher apparent small intestinal amino acid digestibilities, ranging from 60.6 to $67.2 \%$ for alkaline hydrogen peroxide treated wheat straw supplemented with various protein sources fed to sheep. The duodenal amino acid flows' in this experiment were, however, much higher than for AWS in the present experiment.

The quantity of AA-N apparently absorbed from the small intestine was significantly higher for AWS than for UWS and SWS. Since the apparent digestibility of AA-N in the small intestine did not differ between rations, the apparent AA-N absorption was largely determined by the duodenal flow of AA-N. In turn, the differen- 
ce in duodenal flow between rations was mainly determined by a difference in microbial AA-N flow in the duodenum, and, since the efficiency of microbial protein synthesis did not differ between rations to the amount of OM apparently fermented in the rumen.

The endogenous AA-N flow in the proximal duodenum did not differ between ra(jons, Zorrilla-Rios et al. (1991) also did not observe differences between endogenous $\mathrm{N}$. flow in the duodenum between ammoniated wheat straw and wheat straw supplemented with urea.

The small intestinal apparent digestibility of individual amino acids did not differ between rations, except for phenylalanine, which was lower for UWS than for AWS and SWS. The apparent digestibilities of cystine and histidine were low. Storm et al. (1983) observed a low true digestibility of microbial cystine and histidine.

Absorbed amino acids will enter the amino acid pool and can be utilized for tissue maintenance and production. Formation of endogenous protein and supply of $\mathrm{N}$ for microbial protein synthesis can probably be covered by the $\mathrm{N}$ lost in tissue maintenance processes as postulated by Ørskov (1982). Thus the total of urinary and faecal $\mathrm{N}$ excretion of animals fed on $\mathrm{N}$ free diets should be regarded as net maintenance requirements. A value of $250-400 \mathrm{mg} \mathrm{AA-N} / \mathrm{kg}^{0.75} / \mathrm{d}$ was proposed by $Ø$ rskov (1982). Accepting an efficiency of utilization of truly absorbed AA-N of 0.65 (Rohr \& Lebzien, 1991) the maintenance requirements for truly absorbed AA-N are therefore in the range of $380-620 \mathrm{mg} / \mathrm{kg}^{0.75} / \mathrm{d}$. In an experiment with sheep fed untreated and ammoniated wheat straw, the latter either unsupplemented or supplemented with casein or potato protein, Van Bruchem et al. (unpublished) obtained by regression of truly absorbed AA-N on $\mathrm{N}$ balance as estimate of maintenance requirements for AA-N $520 \mathrm{mg} / \mathrm{kg}^{0.75} / \mathrm{d}$. In the present experiment, based on a true small intestinal digestibility of AA-N of 0.85 estimates of truly absorbed AA-N were 337,360 and $490 \mathrm{mg} \mathrm{AA-N} / \mathrm{kg}^{0.75} / \mathrm{d}$ (SEM 19.2) for UWS, SWS and AWS, respectively. This suggests, that maintenance requirements for AA-N were not met for UWS and SWS and could approximately be covered for AWS. As reported by Van Bruchem et al. (1993) the digestible organic matter intake of the sheep in the present experiment was 70, 75 and $133 \%$ of the maintenance requirements for UWS, SWS and AWS, respectively, Comparison of estimates of energy and AA-N availability from the rations in the present experiment indicate, that the AA-N/energy ratio was more or less balanced in case of UWS and SWS, but that for AWS availability of truly absorbed AA-N could only sustain maintenance, while energy intake was above maintenance.

\section{Acknowledgements}

The authors gratefully acknowledge financial support provided by the Commission of the European Communities: Contract TS2-0091-NL, Utilization of crop residues and supplementary feeds in tropical developing countries. They are further indebted to Mr G. A. Bangma, Mrs Ing. A. Waanders, Ms. A.J. Fleurke and Mr D. Vink for taking care of the fistulated animals and conducting the experiments. Ms Yun Insiani and $\mathrm{Mr}$ Jeroen Doorenbos contributed to this research program as students. 


\section{S, J, OOSTING ET AL.}

\section{References : 1 ,}

ARC, 1980. The nutrient requirements of ruminant livestock. Commonwealth Agricultural Bureaux, Farnham Royal, Slough, UK, 351 pp.

Brouwer, B.O., 1989. DBSTAT user's guide. Department of Animal Husbandry, Wageningen Agricultural University, the Netherlands, $20 \mathrm{pp}$.

Cecava, M.J., N.R. Merchen, L.L. Berger \& G.C. Fahey, Jr, 1990. Intestinal supply of amino acids in slieep fed alkaline hydrogen peroxyde-treated wheat straw based diets supplemented with soybean meal or combinations of corn gluten meal and blood meal. Journal of Animal Science 68: 467-477.

Cheng, K.J. \& J.W. Costerton, 1980. Adherent bacteria in ruminant digestion. In: Y. Ruckebush \& P. Thivend (Eds), Digestive Physiology and Metabolism in Ruminants, p. 227-250. MTP Press Limited, Lancaster.

Czerkawski, J.W., 1986. An introduction to rumen studies. Pergamon press, Oxford, 236 pp.

Demeyer, D.I. \& C.J. Van Nevel, 1979: Effect of defaunation on the metabolism of rumen micro-organisms. British Journal of Nutrition 42: 515-524.

De Vries, W., W.M.C. Kapteijn, E.G. van der Beek \& A.H. Stouthamer, 1970. Molar growth yields and fermentation balarices of Lactobacilius casei L3 in batch cultures and in continuous cultures. Journal of General Microbiology 63: 333-345.

Dufva, G.S., E.E. Bartley, M.J. Aramel, T.G. Nagaraja, S.M. Dennis, S.J. Galitzer \& A.D. Dayton, 1982, Diaminopimelic acid content of feeds and rumen bacteria and its usefulness as a rumen bacterial marker. Journal of Dairy Science 65: 1754-1759.

Evans, R.A., R.F.E. Axford \& N.W. Offer, 1975. A method for estimating the quantities of microbial and dietary proteins flowing in the duodenal digesta of ruminants. Proceedings of the Nutrition Soclety 34: 65A.

Harrop, C.J.F., 1974. Nitrogen metabolism in the ovine stomach. 4. Nitrogenous components of the abomasal secretions, Journal of Agricultural Science (Cambridge) 83: 249-257.

Hespell, R.B. \& M.P, Bryant, 1979. Efficiency of rumen microbial growth: influence of some theoretical and experimental factors on $Y_{\text {ATP. }}$. Journal of Animal Science 49: 1640-1659.

Hvelplund, T. \& M. Hesselholt, 1987. Digestibility of individual amino acids in rumen microbial protein and undegraded dietary protein in the small intestine of sheep. Acta Agricultura Scandinavica 37: 469-477.

Hvelplund, T,, 1989. Protein evaluation of treated straws. In: M. Chenost \& P. Reiniger (Eds), Evaluation of Straws in Ruminant Feeding, p. 66-74. Elsevier Science Publishers, Barking.

Isaacson, H.R., F.C. Hinds, M.P. Bryant \& F.N. Owens, 1975. Efficiency of energy utilization by mixed I rumen bacteria in continues culture. Journal of Dairy Science 58: 1645-1659.

Meyer, R.M., E.E, Bartley, C.W. Deyoe \& V.F. Colenbrander, 1967. Feed processing. 1. Ration effects on rumen microbial protein synthesis and amino acid composition. Journal of Dairy Science 50: 13271331.

Moore, S, 1963. On' the determination of cystin as cysteic acid. Journal of Biological Chemistry 238: 235-237.

Nocek, J,E. \& J.B. Russell, 1988. Protein and energy as an integrated system. Relationship of ruminal protein and carbohydrate availability to microbial synthesis and milk production. Journal of Dairy Sclence 71: 2070-2107.

Nolan, J.V. \& S. Stachiw, 1979. Fermentation and nitrogen dynamics in Merino sheep given a lowquality-roughage diet. British Journal of Nutrition 42: 63-80.

Oldham, J.D., 1984. Protein energy relationships in dairy cows. Journal of Dairy Science 67: 10901114.

Ørskpv, E.R, 1982, Protein nutrition in ruminants. Academic Press Inc. Ltd., Harcourt Brace Jovanovich Publishers, London, 160 pp.

Owens, F.N. \& A.L. Goctsch, 1986. Digesta passage and microbial protein synthesis. In: L.P. Milligan, W.L. Grovum \& A. Dobson (Eds), Control of Digestion and Metabolism in Ruminants, p. 196-227. Prentice-Hall, Englewood Cliffs, NJ.

Rolır, K. \& P, Lebzien, 1991. Present knowledge of amino acid requirements for maintenance and production. In: B.O. Eggum et al. (Eds), Protein metabolism and nutrition, p. 127-138. Proceedings of the 
6th international symposium on protein Metabolism and Nutrition. Herning, Denmark, 9-14 June 1991, EAAP-publication No 59. Volume 1. Main reports.

Siddons, R.C., D.E. Beever \& J.V. Nolan, 1982. A comparison of methods for the estimation of microbial nitrogen in duodenal digesta of sheep. British Journal of Nutrition 48: 377-389.

Snedecor, G.W., \& W.G. Cochran, 1967. Statistical Methods. Iowa State University press, Ames, Iowa, $593 \mathrm{pp}$.

Storm, E, D,S, Brown \& E.R. Ørskov, 1983. The nutritive value of rumen micro-organisms in ruminants, 3. The digestion of microbial amino and nucleic acids in, and losses from, the small intestine of sheep, British Journal of Nutrition 50: 479-485.

Storm, E, \& E.R. Ørskov, 1983. The nutritive value of rumen micro-organisms in ruminants. 1. Large scale isolation and chemical composition of rumen micro-organisms. British Journal of Nutrition 50: 463-470.

Tas, M.V, R.A. Evans \& R.F.E. Axford, 1981. The digestibility of amino acids in the small intestine of the sheep, British Journal of Nutrition 45: 167-174.

Van Bruchem, J, S.M.G. Rouwers, G.A. Bangma, S.C.W. Lammers-Wienhoven \& P.W.M. van Adrichem, 1985, Digestion of proteins of varying degradability in sheep. 2. Amount and composition of the protein entering the small intestine. Netherlands Journal of Agricultural Science 33: 273-284.

Van Bruchem, J., Marlou W. Bosch, L.J.G.M. Bongers, G.A. Bangma \& P.W.M. van Adrichem, 1987. Apparent and true digestibility of amino acids in the small intestine of sheep. Effect of dry matter intake and digestibility. In: Proceedings 5th EAAP Symposium on Protein Metabolism and Nutrition, Rostock, p. 13-14. EAAP publication no. 35.

Van Bruchem, J., A.K. Kies, R. Bremmers, M.W. Bosch, H. Boer \& P.W.M. van Adrichem, 1988. Digestion of alfalfa and grass silages in sheep. 2. Digestion of protein in reticulorumen and intestines. Nellerlands Journal of Agricultural Science 36: 365-374.

Yan Bruchem, J., L.J.G.M. Bongers, S.C.W. Lammers-Wienhoven, G.A. Bangma \& P.W.M. van Adrichem, 1989. Apparent and true digestibility of protein and amino acids in the small intestine of sheep as related to the duodenal passage of protein and non- protein dry matter. Livestock Production Sclence 23: 317-327.

Van Bruchem, J, S.J. Oosting, Lammers-Wienhoven, S.C.W. \& C.P. Leffering, 1993. Anhydrous ammonin treatment of wheat straw. 1. Voluntary intake, chewing behaviour, rumen pool size and turnover, and partition of digestion along the digestion tract of sheep. Netherlands Journal of Agricultural Sclence 41: $\mathrm{xxx}-\mathrm{xxx}$.

Van Neycl, C.J. \& D.I. Demeyer, 1979. Stoichiometry of carbohydrate fermentation and microbial growth efficiency in a continuous culture of mixed rumen bacteria. European Journal of Applied Microbiology and Biotechmology 7: 111-120.

Van Socst, P.J., 1982. Nutritional ecology of the ruminant. O \& B books, Corvallis, Oregon, 373 pp.

Voigt, J., U. Schönhausen, R. Krawiclitzki \& B. Platkowski, 1991. Comparison of ${ }^{15} \mathrm{~N}$, amino acid profile, RNA, DAPA and D-alanine as markers for microbial nitrogen flowing to the duodenum of dairy cows, In: B.O. Eggum et al. (Eds), Protein Metabolism and Nutrition, p. 71-74. Proceedings of the 6th international symposium on protein metabolism and nutrition. Herning, Denmark, 9-14 June 1991. BAAP-publication No. 59. Volume 2. Short Communications.

Willms, C.L., L.L. Berger, N.R. Merchen, G.C. Fahey, Jr \& R.L. Fernando, 1991. Effects of increasing crude protein level on nitrogen retention and intestinal supply of amino acids in lambs fed diets based on alkaline hydrogen peroxide-treated wheat straw. Journal of Animal Science 69: 4939-4950.

Zorrilla-Rios, J., G.W. Horn \& R.W. McNew, 1991. Nutritive value of ammoniated wheat straw fed to cnttle, Journal of Animal Science 69: 283-294. 